\title{
How to drive phloem gene expression? A case study with preferentially expressed citrus gene promoters
}

\author{
Yane Caroline dos Anjos Bezerra ${ }^{1}$, João Paulo Rodrigues Marques $^{2}$, Liliane Cristina Liborio Stipp ${ }^{3}$, \\ Lísia Borges Attílio ${ }^{4}$, Juliana Freitas-Astúa ${ }^{5}$, Francisco de Assis Alves Mourão Filho ${ }^{6}$
}

Abstract - New approaches for developing disease-resistant genetically modified organisms have included specific targets for gene expression to enhance the chances for pathogen control. Gene expression driven by phloem-derived Citrus sinensis gene promoters could be evaluated and compared with the expression induced by a strong constitutive promoter in the same tissue, leading to the production of transgenic sweet oranges potentially more resistant to diseases caused by phloem-limited bacteria. 'Carrizo' citrange [Poncirus trifoliata (L.) Raf. x Citrus sinensis (L.) Osbeck] was transformed, via Agrobacterium tumefaciens, with the binary vector pCAMBIA2301 bearing the uidA gene ( $\beta$-glucuronidase) driven by the CaMV35S constitutive promoter (CaMV35S::uidA) or by the CsPP2.B1 (CsPP2.B1::uidA) or by the CsVTE2 (CsVTE2::uidA) citrus promoters. In vitro regenerated shoots were grafted onto 'Rangpur' lime (C. limonia Osbeck). The genetic transformation was confirmed by Southern blot analyses. uidA gene expression was evaluated by RT-qPCR, and gene histolocalization controlled by these three promoters was accessed by X-GLUC treated stem sections. uid A gene expression exhibited by tissue-specific promoters was overall lower than from the constitutive promoter CaMV35; however, constructs driven by tissuespecific promoters may lead to expression in restricted tissues. CsPP2.B1 and CsVTE2 promoters can be considered adequate for the utilization in gene constructs aiming disease resistance.

Index Terms: Candidatus Liberibacter spp.; disease resistance; genetic transformation; GUS; histolocalization.

\section{Como regular a expressão de genes no floema? Um estudo de caso com promotores de genes de citros \\ preferencialmente expressos}

Corresponding author: francisco.mourao@usp.br

Received: February 02,2021 Accepted: May 21, 2021

Copyright: All the contents of this journal, except where otherwise noted, is licensed under a Creative Commons Attribution License.

(cc) EY
Resumo - Novas abordagens para o desenvolvimento de organismos geneticamente modificados, resistentes a doenças, incluem alvos específicos de expressão gênica, visando a aumentar as chances de controle do patógeno. A expressão gênica, induzida por promotores de genes de Citrus sinensis, derivados do floema, poderia ser avaliada e comparada com aquela induzida por um promotor constitutivo no mesmo tecido, levando à produção de laranjas-doces transgênicas, potencialmente mais resistentes a doenças causadas por bactérias de floema. Plantas de citrange 'Carrizo' [Poncirus trifoliata (L.) Raf. x Citrus sinensis (L.) Osbeck] foram transformadas, via Agrobacterium tumefaciens, com o vetor binário pCAMBIA2301 contendo o gene uidA ( $\beta$-glucuronidase), dirigido pelo promotor constitutivo CaMV35S (CaMV35S :: uidA) ou pelos promotores de citros CsPP2.B1 (CsPP2 .B1 :: uidA) ou CsVTE2 (CsVTE2 :: uidA). Brotos regenerados in vitro foram enxertados em limão 'Cravo' ( $C$. limonia Osbeck). A transformação genética foi confirmada por análises de Southern blot. A expressão do gene uidA foi avaliada por RT-qPCR, e a histolocalização do gene, dirigida por esses três promotores, foi acessada por seções de ramos tratadas com X-GLUC. A expressão do gene uidA, exibida por promotores específicos de tecido, foi, em geral, menor do que a do promotor constitutivo CaMV35; no entanto, as construções dirigidas por promotores específicos de tecido podem levar à expressão em tecidos restritos. Os promotores CsPP2.B1 e CsVTE2 podem ser considerados adequados para utilização em construções gênicas, visando à resistência a doenças.

Termos para indexação: Candidatus Liberibacter spp.; resistência a doenças; transformação genética; GUS; histolocalização.

\footnotetext{
${ }^{1}$ M.Sc., Doctoral Student at the Graduate Program in Plant Science, Department of Crop Science, Luiz de Queiroz College of Agriculture, University of São Paulo, Piracicaba-SP, Brazil. Email: yanecaroline.bezerra@gmail.com ${ }^{\text {(ORCID 0000-0001-5688-0180) }}$

${ }^{2}$ Dr., Post-doc at the Laboratory of Nuclear Instrumentation, Center of Nuclear Energy in Agriculture, University of São Paulo, Piracicaba-SP, Brazil

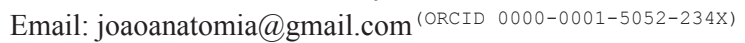

${ }^{3}$ Dr., Laboratory technician at the Department of Crop Science, Luiz de Queiroz College of Agriculture, University of São Paulo, Piracicaba-SP, Brazil. Email: liliane.stipp@usp.br (ORCID 0000-0002-6628-5489)

${ }^{4}$ Dr., Post-doc at the Center of Citriculture Sylvio Moreira, Cordeirópolis-SP, Brazil. Email: lisiaborges@gmail.com ${ }^{\text {(ORCID 0000-0002-0869-353X) }}$ ${ }^{5} \mathrm{PhD}$, Researcher at Embrapa Cassava and Fruit Crops. Cruz das Almas-BA, Brazil. Email: juliana.astua@embrapa.br (0RCID 0000-0002-0506-6880) ${ }^{6} \mathrm{PhD}$, Full Professor at the Department of Crop Science, Luiz de Queiroz College of Agriculture, University of São Paulo, Piracicaba-SP, Brazil. Email: francisco.mourao@usp.br (ORCID 0000-0001-8950-9513)
} 


\section{Introduction}

The production of disease-resistant genetically modified organisms (GMOs) has been significantly increased within the last three decades. In the case of citrus, the first generation of GMOs included the production of transgenic plants expressing reporter genes, normally controlled by strong constitutive promoters. After the optimization of the transformation protocol, GM plants have been produced expressing large spectrum antimicrobial peptides (AMPs) or other candidate genes frequently driven by constitutive promoters. The most recent generation of GMOs for disease resistance has now been produced, including strategies to target gene expression within specific tissues where the potential pathogen is hosted, and also aiming to avoid the unnecessary gene expression in all plant tissues. The idea is to encode specific proteins using tissue promoters to activate the expression of a certain gene in a particular cell type without causing any changes in the whole plant tissues (ALI; KIM 2019). Moreover, the DNA sequencing results from different species have allowed the identification of tissue-specific expressed genes and their respective promoters, leading to a broad possibility of their use (DUTT et al. 2012; DONMEZ et al. 2013). Therefore, the search and evaluation of new tissue-specific promoters, derived from their own plant species, that could directly or preferentially target gene expression within the pathogen preferential site of colonization, could be very beneficial for applying these new strategies on the production of potentially disease-resistant GMOs (SCHAART et al. 2016).

In citrus, huanglongbing (HLB) is considered one of the most devastating diseases that threaten the citrus industry worldwide. HLB-associated bacteria (Candidatus Liberibacter spp.) can grow inside the sieve tube elements of the phloem (STEs), leading to significant changes in the metabolism of the infected plants (BOVÉ 2006). Soon after the HLB report in Brazil, two species were found associated with this disease, $\mathrm{Ca}$. $\mathrm{L}$. americanus ( $C \mathrm{Lam})$, and $\mathrm{Ca}$. L. asiaticus ( $C \mathrm{Las})$, both transmitted through contaminated tissues or by the Asian citrus psyllid Diaphorina citri Kuwayama (Hemiptera: Liviidae) (TEIXEIRA et al. 2005). Surveys conducted in the following years revealed that $C$ Las has been the predominant species in citrus groves in Brazil (SILVA et al. 2019), in Florida, USA, and worldwide (FOLIMONOVA et al. 2009).

Hypertrophy and hyperplasia in parenchyma cells of HLB infected plants have been reported for decades (SCHNEIDER, 1968). Recent ultrastructural studies revealed that early stages of $C$ Las infection in sweet orange plants include a significant swelling of the middle lamella between cell walls, around the sieve elements. Plants with advanced symptoms of HLB infection show necrotic phloem cell parenchyma pocket formations, leading to an interruption in the flow of photoassimilates, and, consequently, to a sequence of events that result in the disease symptoms, including leaf yellowing (leaf mottling), plant stunting, small, irregular, and acid fruits, aborted seeds, and, consequently, yield reduction leading to grove economical unviability (FOLIMONOVA; ACHOR 2010).

Sieve tube elements colonization by the HLBassociated bacteria causes anatomical modifications of the phloem tissues, triggers plant defense mechanisms that involve the action of structural proteins (P-proteins), and induces callose deposition in injured STEs, preventing the transport of photoassimilates to the root system (FOLIMONOVA; ACHOR 2010; ETXEBERRIA; NARCISO 2012). Thus, P-proteins have a fundamental role in the plant defense mechanism against sap loss caused by injuries, as well as other functions during pathogen and pest defenses (READ; NORTHCOTE 1983; VAN BEL 2003). In general, two types of P-proteins are very abundant in the sap of angiosperms: Phloem Protein 1 (PP1) and Phloem Protein 2 (PP2) (EVERT 2006). In the peripheral cytoplasm of mature STEs, the function of $\mathrm{P}$-proteins is analogous to an endoskeleton, keeping the cytoplasm of these specialized cells in a parietal position, i.e., close to the cell walls (MACHADO; CARMELLOGUERREIRO 2012). The production site of these proteins is attributed to the companion cells of the sieve tube/ companion cell complexes, where they are synthesized and then transported to the STEs through the plasmodesmata (READ; NORTHCOTE 1983). In citrus, the induction of PP2 expression was reported in the presence of $C$ Las and CLam (ACHOR et al. 2010; ALBRECHT; BOWMAN 2012; MAFRA et al. 2013; BOAVA et al. 2017).

In addition to PP2 genes, other genes involved in the phloem functionality have also been identified and are induced by the presence of the HLB-associated bacteria (MAFRA et al. 2013). Among those identified transcripts, a homogentisate fitiltransferase (VTE2), encodes an enzyme involved in tocopherol biosynthesis. Tocopherols are important antioxidants in the protection and adaptation of plants to the environment, and are responsible for loading substances into the phloem (MAEDA et al. 2006; MAFRA et al. 2013; MAEDA et al. 2014).

Information about the role of proteins related to the phloem tissue can create new possibilities of use in genetic engineering. Knowing the site of the protein expression driven by their promoters with reporter genes will reveal the strength and specificity of their expression. Those promoters can be used in gene construct aiming at vascular disease control, such as HLB, along with other strategies for disease control, e.g., plant defensins (LAY; ANDERSON 2005). 
In citrus, there are few studies aiming to evaluate gene expression in constructs driven by endogenous, pathogen-induced or tissue-specific promoters (DUTT et al. 2012, ZOU et al. 2014), including some studies from our group (MIYATA et al. 2012; MIYATA et al. 2017). Considering these facts, we evaluated other gene constructs bearing different citrus promoters potentially expressed in the phloem tissue driving the uidA reporter gene expression (encoding the $\beta$-glucuronidase (GUS) protein), through more detailed molecular and histological analyses, in an attempt to select tissue-specific citrus promoters, for further use in gene constructs targeting the control of HLB.

\section{Materials and Methods}

\section{Promoter isolation and construction of expression vectors}

The sequences promoters VTE2 (Homogentisate phytyltransferase - accession number orange $1.1 \mathrm{~g} 015340 \mathrm{~m} . \mathrm{g})$ and PP2.B1 (F-Box Phloem protein $2-B 1$ - related - accession number orange $1.1 \mathrm{~g} 024543 \mathrm{~m} . \mathrm{g}$ ) were identified from Citrus sinensis gene in database Phytozome (https//:phytozome. org). The promoter fragments CsVTE2 and CsPP2.B1 were PCR amplified from $C$. sinensis genomic DNA, using specific primers designed to amplify $904 \mathrm{bp}$ and $475 \mathrm{bp}$, respectively. In spite of having a relatively short sequence, specially for the CsPPs.B1, the constructions bear all the necessary regulatory elements for adequate uidA gene expression. The promoters were cloned into pCAMBIA 2301 binary vector, replacing the CaMV35S promoter that controls the uidA gene (Figure 1). The original pCAMBIA2301 containing CaMV35S::uidA was used as control. All expression vectors were introduced into the Agrobacterium tumefaciens strain EHA105.

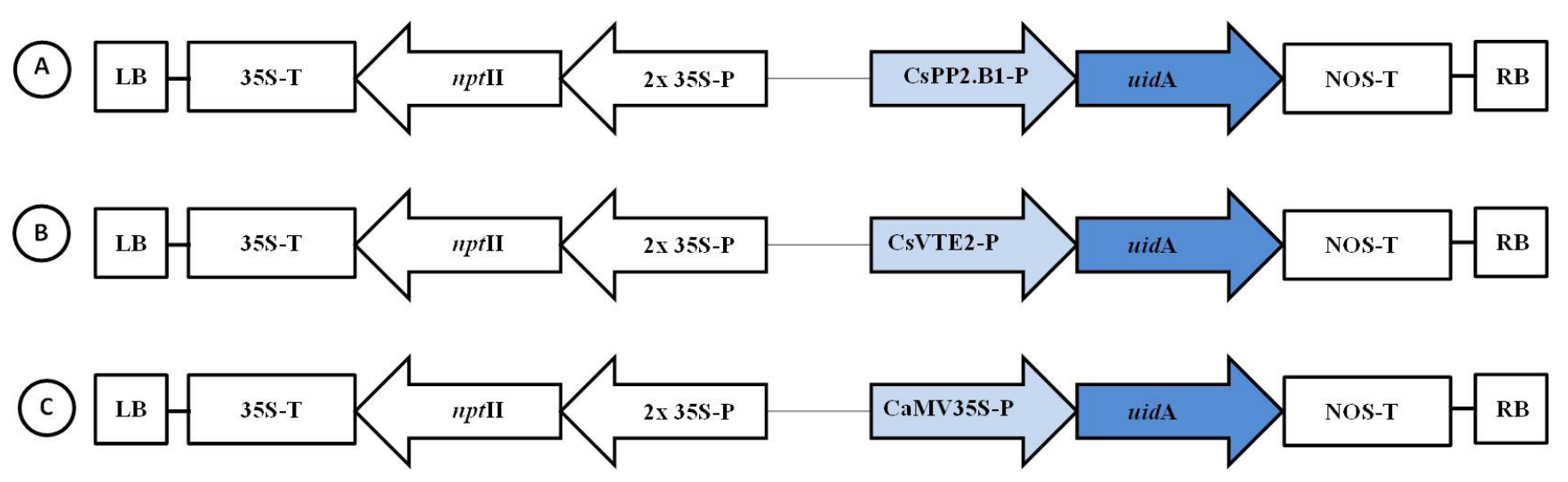

Figure 1. Schematic representation of the transfer region (T-DNA) in the three gene constructions, bearing the uidA gene, driven by three different promoters, and utilized to produce and evaluate different transgenic events. A: pCAMBIA2301/CsPP2.B1::uidA binary vector; B: pCAMBIA2301/CsVTE2::uidA binary vector; C: pCAMBIA2301/ CaMV35S::uidA binary vector. nptII: kanamycin antibiotic resistance gene; 2xCaMV35S: CaMV35S duplicated promoter; 35S-T: 35S-T terminator; NOS-T: nopaline synthase terminator; LB: left border; RB: right border.

\section{Plant transformation and regeneration}

Epicotyl segments $(0.8-1.0 \mathrm{~cm})$ of 'Carrizo' citrange plants $[P$. trifoliata (L.) Raf. x C. sinensis (L.) Osbeck] obtained from in vitro germinated seedlings were used for genetic transformation. Explants were inoculated with $A$. tumefaciens EHA105, containing expression vectors. After inoculation, the explants were transferred to MT medium supplemented with BAP (1.0 $\mathrm{mg} \mathrm{L}^{-1}$ ) for 2-day co-cultivation period at $24^{\circ} \mathrm{C}$. Explants were transferred selection medium MT supplemented with BAP (1.0 $\left.\mathrm{mg} \mathrm{L}^{-1}\right)$, kanamycin $\left(100 \mathrm{mg} \mathrm{L}^{-1}\right)$ and cefotaxime sodium $\left(500 \mathrm{mg} \mathrm{L}^{-1}\right)$. Cultures were incubated in the dark for 4 weeks at $27^{\circ} \mathrm{C}$, and then transferred to a 16 -h photoperiod at $27^{\circ} \mathrm{C}$. The developed shoots were ex vitro grafted onto 'Rangpur' lime (C. limonia Osbeck) (MIYATA et al., 2012). Acclimated transgenic plants were then cultivated in a greenhouse in order to be later evaluated. Six-year-old transgenic plants were used in the experiments. Plants were grown in 4.8-liter plastic bags with a commercial potting mix based on pine-bark and vermiculite (Multiplant ${ }^{\circledR}$-Terra do Paraíso, Holambra, Brazil), and cultivated with weekly nutrient applications through fertigation. 


\section{Southern blot}

The Southern blot analysis was carried out following standard procedures in all experimental plants to confirm the genetic transformation and to verify the number of insertion events in the citrus genome. Genomic DNA was extracted by the cetyltrimethylammonium bromide (CTAB) method (DOYLE; DOYLE, 1990), from the young well-developed leaves of acclimatized plants. DNA samples were quantified by the Qubit ${ }^{\mathrm{TM}}$ Fluorometer using QuantiT ${ }^{\mathrm{TM}}$ dsDNA BR assay kit (Invitrogen, Carlsbad, USA). The DNA (10 to $30 \mu \mathrm{g}$ ) was digested for $16 \mathrm{~h}$ with the EcoRI restriction enzyme

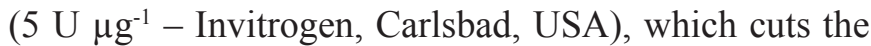
T-DNA in only one site. The digested DNA was separated by electrophoresis on a $0.8 \%$ agarose gel $\left(1.3 \mathrm{~V} \mathrm{~cm}^{-1}\right.$, $16 \mathrm{~h}$ ), transferred to a nylon membrane (Amersham Hybond-N+TM - GE Healthcare, Buckinghamshire, UK) by capillarity and the DNA was fixed at $80^{\circ} \mathrm{C}$, for $2 \mathrm{~h}$. The $416 \mathrm{bp}$ PCR product of the coding sequence of the uidA gene was labelled with alkaline phosphatase (Amersham AlkPhos Direct ${ }^{\mathrm{TM}}$ Labelling Reagents; GE Healthcare, Buckinghamshire, UK). Pre-hybridization, hybridization $\left(60{ }^{\circ} \mathrm{C}\right)$ and membrane washings were performed following the supplier's instructions. The detection was performed with Amersham CDP - Star ${ }^{\mathrm{TM}}$ Detection Reagent (GE Healthcare, Buckinghamshire, UK) and the membranes were analyzed by autoradiography (Amersham Hyperfilm ${ }^{\mathrm{TM}}$ ECL, GE Healthcare, Buckinghamshire, UK).

\section{Analysis of transgene expression by quantitative real-time PCR (qPCR)}

Total RNA was extracted from young welldeveloped leaves by the Lithium Chloride method (CHANG et al. 1993), modified to 5\% CTAB. Extracted RNA was treated with DNase I - Rnase-free (Thermo Scientific, Vilnius, Lithuania), and was quantified and 260/280 ratios were estimated using NanoDrop 8000 Spectrophotometer (Thermo Fisher Scientific, Wilmington, USA). The RNA integrity was evaluated in a $1.5 \%$ agarose gel. cDNA synthesis, corresponding to each sample were generated using Platus Transcriber RNase H- cDNA First Strand kit (Sinapse Inc, Hollywood, USA) and following the manufacturer's protocol, using $1 \mu \mathrm{g}$ of RNA. PCR was performed for three biological replicates, with three technical replicates from each transgenic plant, non-transgenic plant and water as control. The qPCR was performed using GoTaq ${ }^{\mathrm{TM}}$ qPCR Master Mix (Promega, Madison, USA) on 7500 Fast $^{\mathrm{TM}}$ Real-Time PCR System (Applied Biosystems, Foster City, USA). The reaction was accomplished using $3.0 \mu \mathrm{L}$ cDNA and $300 \mathrm{nM}$ of each gene-specific primer in a final volume of $15.5 \mu \mathrm{L}$.

Quantification cycle $(C \mathrm{q})$ values and primer pairs efficiencies were determined for each individual reaction using Real-time PCR Miner (ZHAO; FERNALD 2005). Gene expression analyses were performed according to the $\triangle C \mathrm{q}$ model using $F$-box and Efl- $\alpha$ reference genes (MAFRA et al. 2013) (Table 1) to verify uidA gene expression in the citrus transgenic plants.

The efficiency of qPCR amplification and threshold cycle $(\mathrm{Ct})$ for each gene were obtained using the Miner web-based tool (http://ewindup.info/miner/) from raw data of the kinetics of individual qPCR assay, according to Zhao and Fernald (2005). The relative quantification of gene expression level was calculated using the GenEx v2.6.4 software (MultiD analysis, Exiqon, USA).

Table 1. Primer sequences utilized for $f-b o x$, efl- $\alpha$ and $u i d$ A genes amplifications in qPCR analyses, and estimated sizes of the respective amplicons.

\begin{tabular}{lllc}
\hline Gene & \multicolumn{1}{c}{ Sequence 5'-3' $F$} & \multicolumn{1}{c}{ Sequence 5'-3' $R$} & Amplicon (bp) \\
\hline$f$-box & TTGGAAACTCTTTCGCCACT & CAGCAACAAAATACCCGTCT & 112 \\
efl- $\alpha$ & TCAGGCAAGGAGCTTGAGAAG & GGCTTGGTGGGAATCATCTTAA & 80 \\
uidA & TGTGGAGTATTGCCAACGAA & GAGCGTCGCAGAACATTACA & 135 \\
\hline
\end{tabular}




\section{Histolocalization of $\mathrm{uidA}$ gene expression}

Free-hand longitudinal and cross-sections were made in $3-5 \mathrm{~cm}$ portions of young shoots, $15 \mathrm{~cm}$ from the shoot apical meristem. Stem sections were immersed in X-GLUC solution (1 mM) (JEFFERSON et al. 1987) and incubated for 30 to 120 minutes at $37^{\circ} \mathrm{C}$ in darkness. The time of incubation varied according to the necessity for the tissue to react with the X-GLUC solution. After the incubation period, the samples were washed according to the methodology of Jefferson et al. (1987) with ethanol:acetic acid solution (3:1) to stop the enzymatic reaction and tissue diaphanization. To visualize the uidA gene expression, the microscope slides were mounted in ethanol $(70 \%)$. To detect the nucleus of the STEs companion cells, the sections were hydrated in decreasing ethylic series $(70,50,30,10 \%)$, and then washed in distilled water and stained with DAPI fluorescent dye (0.1 $\mu \mathrm{g} \mathrm{mL}^{-1}$ in phosphate buffer) (RUZIN 1999). In order to obtain an overview of uidA gene expression, low magnification images were captured in a Leica M205 C stereomicroscope coupled to a Leica DFC295 video camera, LAS 4.0 software. For the high magnification, the slides were observed under the Leica DM5500B epifluorescence microscope with a coupled Leica DFC295 video camera. For the DAPI-stained sections analysis, the DAPI filter (Ex: 340-380 nm; Em: $425 \mathrm{~nm}$ ) was used.

\section{Results and Discussion}

\section{Southern blot}

The transgene insertion was confirmed in 16 plants for the CsPP2.B1::uidA construct, in eight plants for the CsVTE2 uidA construct, and in three plants for the CaMV35S::uidA construct. No signs of hybridization were observed in DNA samples from non-transgenic plants, used as negative controls. The Southern blot positive plants were then used in further analyses. The number of copies of the transgenes varied from one to two, with most plants exhibiting a single copy. The T-DNA insertions occurred in different genome positions within the evaluated plants bearing the different gene constructs (Figure 2).

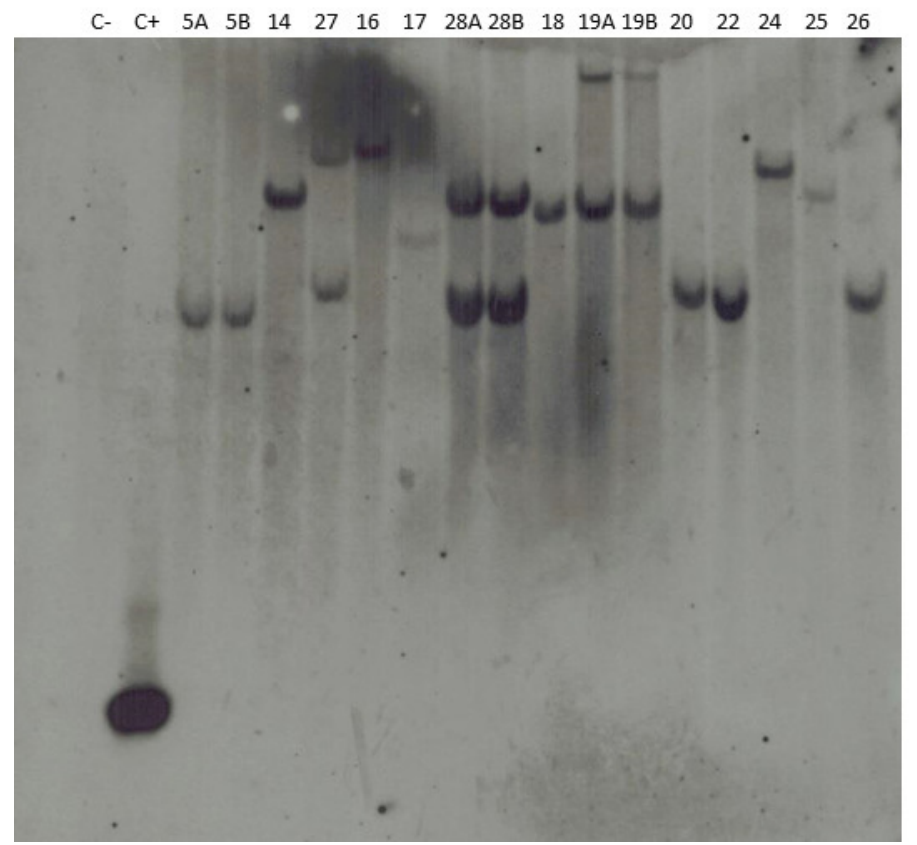

Figure 2. Southern blot analysis in 'Carrizo' citrange [Poncirus trifoliata (L.) Raf. x Citrus sinensis (L.) Osbeck] transgenic plants $\mathrm{C}$-: Negative control (DNA from non-transgenic plant); $\mathrm{C}+$ : Positive control (fragment of the uidA gene). 5A, 5B, 14 and 27: CsPP2.B1::uidA gene construct; 28A, 28B, 18, 19A, 19B, 20 and 22: CsVTE2::uidA gene construct; 24-26: CaMV35S::uidA gene construct. The DNA of all samples was digested with EcoRI restriction enzyme and hybridized with a probe containing the uidA gene amplicon. 


\section{Analysis of transgene expression by quantitative real-time PCR (qPCR) \\ The qPCR analysis was carried out in transgenic} plants that were confirmed by Southern blot analysis. One transgenic plant bearing the CsPP2.B1::uidA construct was used to calculate the relative expression in other transgenic plants, since it exhibited the lowest gene expression of the target gene (uidA).
The uidA gene expression had great variation among plants and among different promoters, ranging from 2.5 to 21.3 times for CsPP2.B1, from 7.3 to 107.5 times for CsVTE2, and from 46.1 to 258 times for CaMV35S gene constructs (Figure 3).

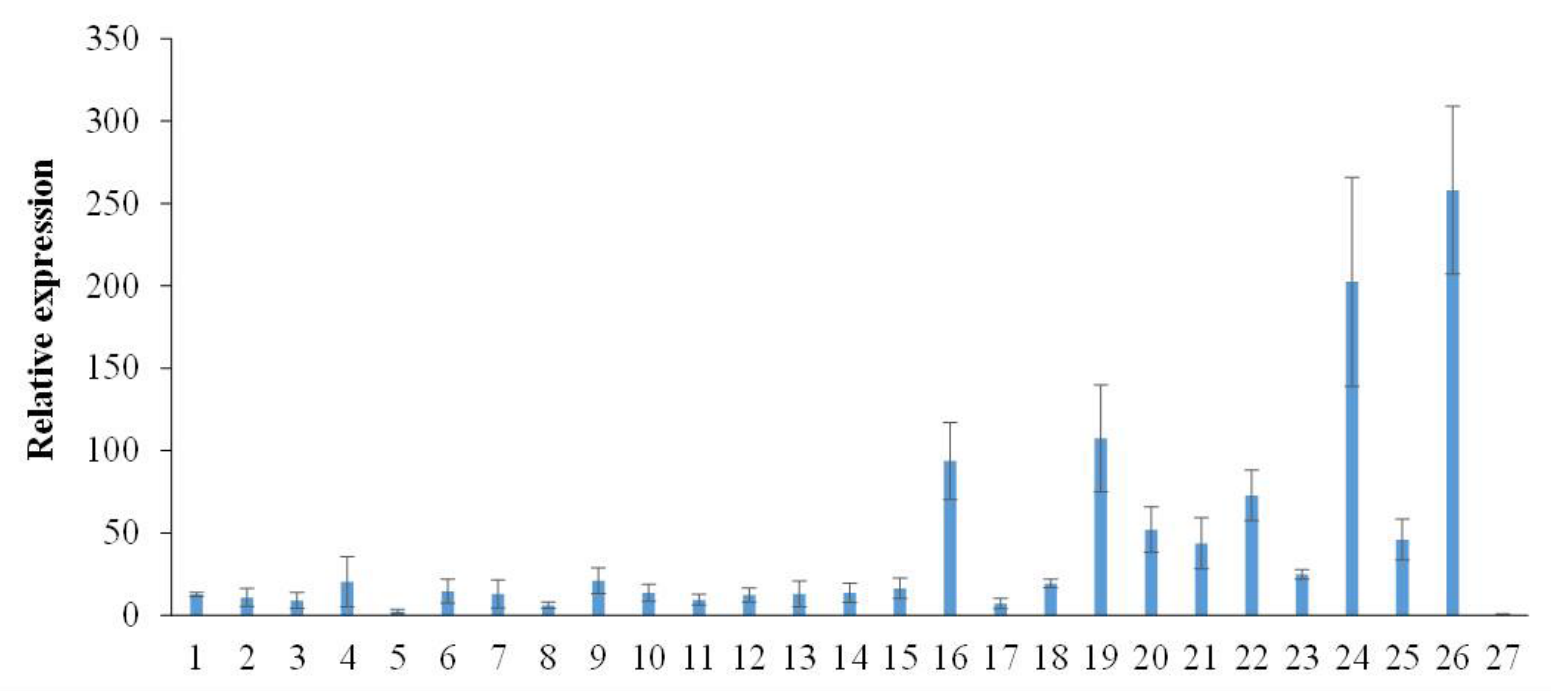

Figure 3. Quantification of the uidA gene expression driven by different promoters in 'Carrizo' citrange [Poncirus trifoliata (L.) Raf. x Citrus sinensis (L.) Osbeck] transgenic plants. 1-15; 27: CsPP2.B1 promoter. 16-23: CsVTE2 promoter. 24-26: CaMV35S promoter. Plant \#27 was used as the calibrator.

The CaMV35S promoter was chosen as a gold standard to compare the expression levels of this wellknown strong and constitutive promoter with the gene expression levels induced by the new promoters evaluated in this work. The results from the qPCR analyses indicated that the average gene expression induced by the CsPP2.B1 and CsVTE2 promoters was approximately $7 \%$ and $31 \%$ of the expression level induced by CaMV35S promoter, respectively.

\section{Histolocalization of uidA gene expression}

The histological analysis allowed the characterization of the expression sites of the GUS reporter gene (uidA) driven by the different promoters (Figures 4; $5 ; 6$ ). The control treatment (non-transgenic plant) showed no reaction to the X-GLUC treatment (Figures 4A; E). In the transgenic plants, the product of the GUS reaction could be seen in different tissues. For the gene construct in which uidA expression was driven by the CaMV35S constitutive promoter, the blue staining was detected in all the stem tissues (Figures $4 \mathrm{~B} ; \mathrm{F}$ ).
Plants containing the uidA gene driven by the CsPP2.B1 or CsVTE2 promoters showed $\beta$-glucuronidase expression in specific tissues. In tissue samples from plants with the gene construct driven by the CsPP2.B1 promoter, the blue staining resulting from the enzymatic activity was observed, preferentially, in the phloem tissue (Figures $4 \mathrm{C}$; $\mathrm{G}, 5 \mathrm{~B} ; \mathrm{C})$. On the other hand, $\beta$-glucuronidase activity was not observed in the cortex and in the epidermis (Figure $5 \mathrm{~A}$ ). In a more detailed examination, it was possible to identify that the product of the GUS reaction occurred within the sieve elements. The $\beta$-glucuronidase reaction product was observed in the sieve plate or adjacent to the walls of the sieve tubes elements (Figures 5D; E). The use of DAPI in the longitudinal stem sections from plants containing the gene construct under the control of the CsPP2.B1 promoter showed cells with nuclei that characterize companion cells adjacent to sieve tube elements (Figure 5F). Moreover, high amounts of the $\beta$-glucuronidase reaction product were observed in the companion cells (Figures 5E; F). 


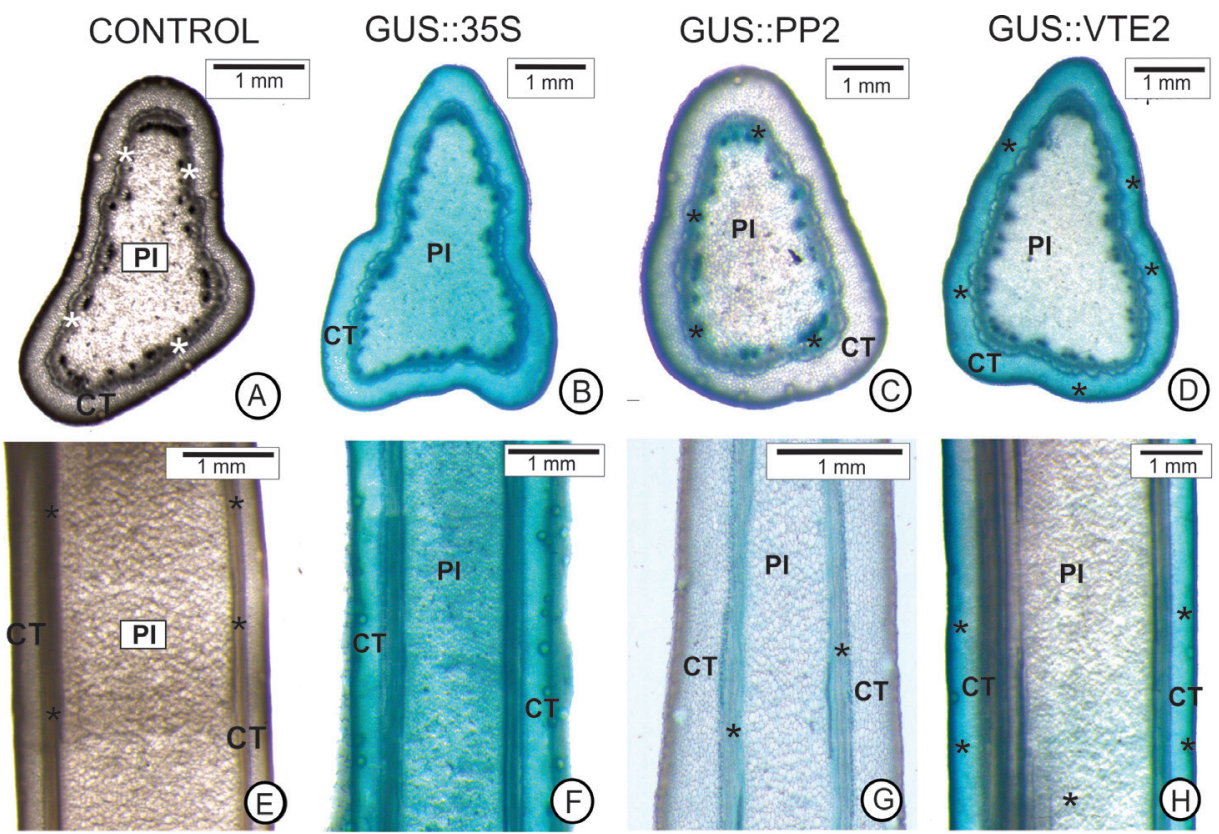

Figure 4. Histochemical assay for the detection of uidA (GUS) gene activity under the control of CaMV35S, CsPP2.B1, and CsVTE2 promoters. Cross (A-D) and longitudinal (E-H) sections of young branches of 'Carrizo' citrange [Poncirus trifoliata (L.) Raf. x Citrus sinensis (L.) Osbeck]. Images were taken using a stereomicroscope. A, E: Negative control (non-transformed plants). B, F: CaMV35S::uidA. The transgenic expression is seen in all tissues of the stem. C, G: CsPP2.B1::uidA. Expression of uidA gene mainly in the phloem region $(*)$. D, H: CsVTE2::uidA. Expression of uidA gene mainly in the cortical region $(*)$. CT: Cortex; PI: Pith.
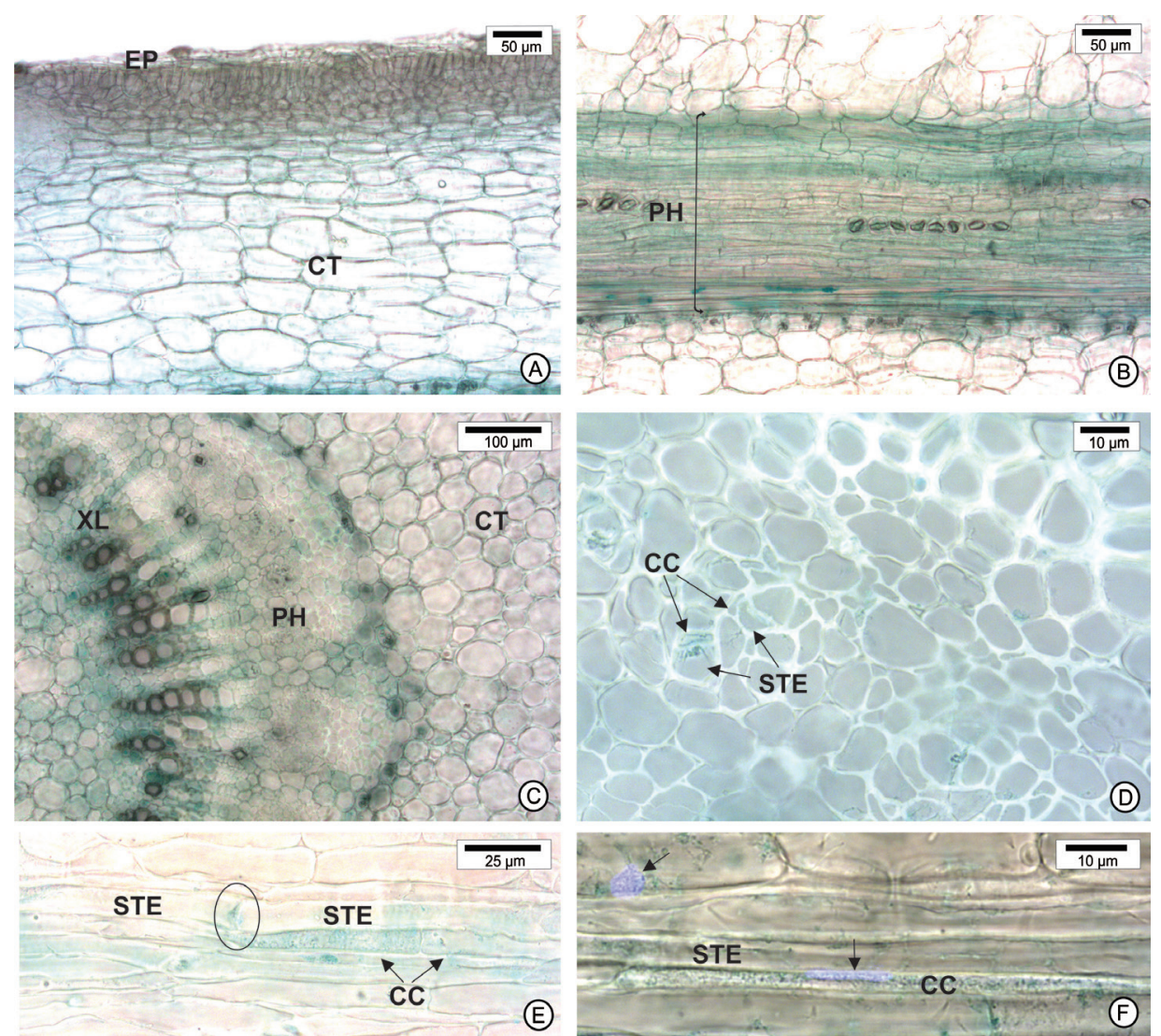

Figure 5. The expression of the uidA(GUS) gene under the control of CsPP2.B1 promoter, detected by light microscopy in young branches of 'Carrizo' citrange [Poncirus trifoliata (L.) Raf. x Citrus sinensis (L.) Osbeck]. Longitudinal (A, B, E, F) and cross (C-D) sections. A: Cortical region. No $\beta$-glucuronidase enzyme reaction was seen. B: Phloem showing cells with a positive reaction. C: Cross-section pointing to the phloem. D: Detailed region of the phloem. Sieve tube elements (STE) and companion cells (CC) indicating the uidA gene expression at the cell wall that separates STE and CC (arrows in E). E: longitudinal section indicating the deposition of the $\beta$-glucuronidase reaction product on the sieve plate (circle) and into the STEs. F: Merged image with bright field and DAPI filter. The cell nucleus showed blue fluorescence (arrows). Companion cells showed a marked nucleus and deposition of the $\beta$-glucuronidase reaction product. EP: Epidermis; CT: Cortex; PH: Phloem; XL: Xylem. 
The analysis of transgenic plants containing the gene construct under the control of the CsVTE2 promoter showed a strong presence of the $\beta$-glucuronidase reaction product in the cortical parenchyma, especially in the regions close to the epidermis (Figures 4D; H). The blue staining was also detected near the phloem, indicating that, despite probably being non-phloem-specific, this promoter drives the expression to or nearby the phloem tissue
(Figure 6A). The presence of $\beta$-glucuronidase reaction was observed in the outer layers of the cortical parenchyma that contains chloroplasts, that is, the chlorenchyma (Figures 6B; C). This intrinsic relationship with chloroplasts was also observed in the epidermis, where only the cells with chloroplasts, the guard cells, also had the blue staining derived from the $\beta$-glucuronidase activity, unlike the ordinary cells of the epidermis (Figure 6D).

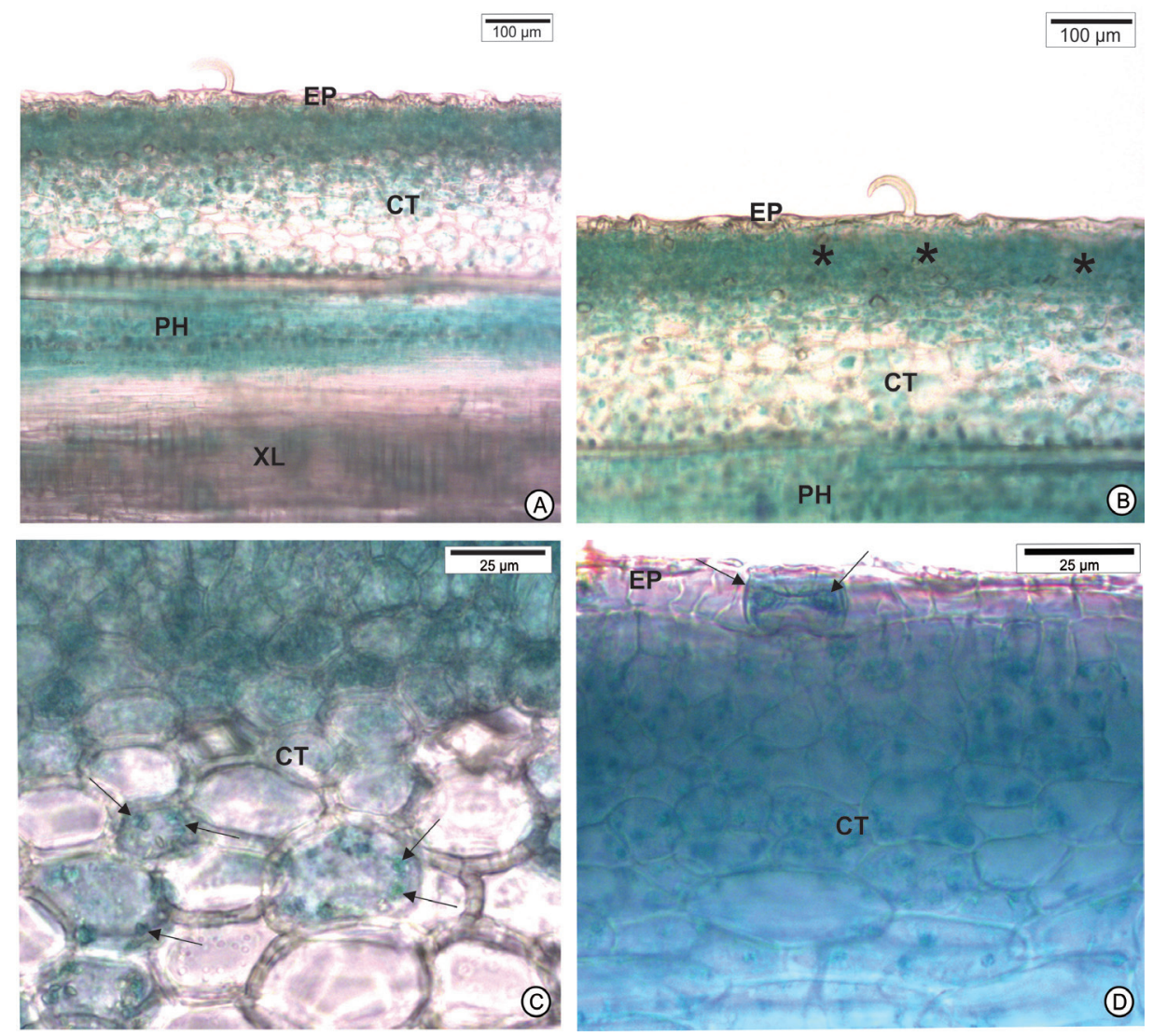

Figure 6. The expression of the uidA (GUS) gene under control of CsVTE2 promoter detected by light microscopy in young branches of 'Carrizo' citrange [Poncirus trifoliata (L.) Raf. x Citrus sinensis (L.) Osbeck]. Cross (C) and longitudinal (A, B; D) sections. A: Overview of vascular tissue, cortical parenchyma and epidermis. No $\beta$-glucuronidase enzyme reaction was seen at xylem and epidermis. B: Cortical parenchyma $\left(^{*}\right)$ showing cells with a positive reaction. C: Detailed cortex. A considerable expression is seen in cells with chloroplasts (arrows). D: Detailed view of the epidermis. The arrow points to a stoma and with its guard cells, the only epidermal element with GUS positive reaction. EP: Epidermis; CT: Cortex; PH: Phloem; XL: Xylem.

Genetic engineering has been widely used to obtain genotypes of agronomic interest with potentially accurate results (DUTT et al. 2015). However, in most cases, the transgenes are driven under the control of constitutive promoters. Tissue-specific promoters have been reported in the literature for different species, including citrus (WANG et al. 1992; TRUERNIT; SAUER 1995; IMLAU et al. 1999; ZHAO et al. 2004; DUTT et al. 2012; MIYATA et al. 2012; DUTT et al. 2014). However, most of these promoters are derived from genetically distant organisms of the species of interest, which may hinder the acceptance of these GMOs (LASSEN et al. 2002). Therefore, the use of cisgenes may bring several benefits (JACOBSEN; SCHOUTEN 2009).
Here, we report the expression levels of two new tissue-specific citrus promoters and compare these results with the expression of the strong, constitutive and heterologous CaMV35S promoter. Our results indicate differences among uidA gene expressions driven by these promoters, showing a variation in relative expression. The expression of the gene uidA when controlled by the CaMV35S promoter was higher than the expression driven by citrus tissue-specific promoters. These results were expected because tissue-specific promoters are restricted to the expression site, whereas the CaMV35S promoter is expressed in all tissues. On the other hand, specific citrus constitutive promoters CYP, GAPC2, and EF1 were recently described by our group, demonstrating 
its potential of reduction in inter-individual variation of transgene expression (ERPEN et al. 2018).

The CsPP2.B1 promoter showed expression in phloem tissue, which can be verified by the presence of the blue staining as a result of the reaction of the uidA gene with the X-GLUC substrate. These results corroborate those reported by Miyata et al. (2012), who demonstrated the importance of the uidA gene in the phloem tissue of transgenic sweet orange plants of different cultivars containing an Arabidopsis thaliana (AtPP2) PP2 derived promoter. The $\beta$-glucuronidase reaction product was observed in phloem tissue, especially in companion cells (CC) and sieve tube elements (STEs). When mature, the complex CC-STEs is a functional unit of the phloem and is separated from the neighbor cells through symplastic isolation (OPARKA; TURGEON 1999). Companion cells are the only nucleated phloem cells and, therefore, is where both mRNA expression and translation of proteins and small RNAs occur in cells (LOUGH; LUCAS 2006). Regarding the PP2 mRNA, it was demonstrated that it is expressed in the CC, however, the protein is also observed in the STE (DANNENHOFFER et al. 1997; DINANT et al. 2003). Based on the information that uidA gene expression is driven by CsPP2.B1 promoter in the CC and the $\beta$-glucuronidase reaction product was observed in both CC and STE cells, we cannot affirm whether the uidA protein or the mRNA is exported from the companion cells to the STEs. Additional immunohistochemical and in situ hybridization assays need to be conducted to shed light on the CsPP2.B1 promoter functional role. CsPP2. $\mathrm{B} 1$ promoter showed expression in phloem tissue, which can be verified by the presence of the blue staining as a result of the reaction of the uidA gene.

The expression pattern of the reporter gene in transgenic plants bearing the construct driven by the CsVTE2 promoter suggests that the expression targeted to the cortical parenchyma, mainly close to the epidermis, as well as to the phloem tissue. Because VTE genes are involved in the tocopherol biosynthesis and these substances have an important role in the oxidative stress and in loading of photoassimilates, this can explain the expression sites of the reporter gene. Tocopherols are synthesized in photosynthetically active cells, what could explain the directed expression of the reporter gene in the cortical parenchyma, where there is a high chloroplast concentration (YABUTA et al. 2013). Besides the strong expression in the cortical parenchyma, the $\beta$-glucuronidase reaction product was detected in the stomatal guard cells in the epidermis. In the analyzed samples, guard cells are the only cells in the epidermis that have chloroplasts, increasing, therefore, the evidence of the strong relationship between this promoter to the plastids (EVERT 2006; YABUTA et al. 2013). Also, immunocytochemical assays identify the presence of VTE inside the plastid plastoglobule (AUSTIN et al. 2006).

In general, uidA gene expression driven by CsVTE2 promoter was higher than that driven by CsPP2. B1 promoter (Figures $4 \mathrm{C} ; \mathrm{D}$ ) but similar to the expression levels driven by the $A t \mathrm{SUC} 2$ promoter reported by Benyon et al. (2013) and Tavano et al. (2015). Though the AtSUC2 promoter drives the expression to specific phloem tissues with good expression levels, this promoter is derived from A. thaliana, a phylogenetic distant organism from citrus. Based on the results here presented, we suggest that the CsVTE2 promoter is potentially interesting to be used in citrus genetic transformation, once it is derived from citrus.

Research studies carried out with biosynthetic VTE mutants in Arabidopsis, have demonstrated the importance of the tocopherols, not only in photoprotection against oxidative stress but also in the loading of photoassimilates and in plant acclimation to low temperatures. Tocopherol deficient VTE2 mutants presented an inhibition in photoassimilate transport, followed by an increase in sugar levels and starch accumulation in the leaves, coinciding with callose deposition in the phloem parenchyma, which, in turn, was later also accumulated in the cells of the sieve tube element complex and companion cells (MAEDA et al. 2006). The damage caused to the flow of photoassimilates is one of the main factors that negatively affect the Liberibacter-infected plants, so this sequence of events is similar to what occurs in infected plants with the HLB-associated bacteria, in citrus (BOVÉ 2006).

The levels of expression exhibited by tissuespecific promoters were lower than those driven by the constitutive promoter CaMV35S; however, constructs that have tissue-specific promoters may lead to expressions in restricted and relevant tissues.

\section{Conclusions}

CsPP2.B1 and CsVTE2 citrus promoters can be considered adequate for their utilization in gene constructs aiming disease resistance, as an alternative to the use of constitutive and/or tissue-specific promoters isolated from organisms phylogenetically distant from citrus. 


\section{Acknowledgments}

The first author acknowledges Coordenação de Aperfeiçoamento de Pessoal de Nível Superior (CAPES) for the MSc student fellowship. FAAMF and JFA acknowledge Conselho Nacional de Desenvolvimento Científico e Tecnológico (CNPq) for research fellowships. JFA acknowledges CNPq for financial support (Proc. 481728/2013-9). The authors thank Dr. Polyana Kelly Martins for support on elaboration of gene constructs. The authors thank Prof. Dr. Beatriz Appezzato-da-Glória for providing the structure for histological analysis.

\section{References}

ACHOR, D.S.; ETXEBERRIA, E.; WANG, N.; FOLIMONOVA, S.Y.; CHUNG, K.R.; ALBRIGO, L.G. Sequence of anatomical symptom observations in citrus affected with huanglongbing disease. Plant Pathology Journal, Deira, v.9, p.56-64, 2010.

ALBRECHT, U.; BOWMAN, K.D. Transcriptional response of susceptible and tolerant citrus to infection with Candidatus Liberibacter asiaticus. Plant Science, Amsterdam, v.85, p.118-130, 2012.

ALI, S.; KIM, W. A fruitful decade using synthetic promoters in the improvement of transgenic plants. Frontiers in Plant Science, Lausanne, v.10, p.1433, 2019.

AUSTIN, J.R.; FROST, E.; VIDI, P.A.; KESSLER, F.; STAEHELIN, L.A. Plastoglobules are lipoprotein subcompartments of the chloroplast that are permanently coupled to thylakoid membranes and contain biosynthetic enzymes. The Plant Cell, Rockville, v.18, p.1693-1703, 2006.

BENYON, L.S.; STOVER, E.; BOWMAN, K.D.; NIEDZ, R.; SHATTERS JR, R.G.; ZALE, J.; BELKNAP, W. GUS expression driven by constitutive and phloem-specific promoters in citrus hybrid US-802. In Vitro Cellular \& Developmental Biology-Plant, Cambridge, v.49, p.255$265,2013$.

BOAVA, L.P.; CRISTOFANI-YALY, M.; MACHADO, M. Physiologic, anatomic, and gene expression changes in Citrus sunki, Poncirus trifoliata and their hybrids after 'Candidtus Liberibacter asiaticus' infection. Phytopathology, Saint Paul, v.107, p.590-599, 2017.
BOVÉ, J.M. Huanglongbing: a destructive, newlyemerging, century-old disease of citrus. Journal of Plant Pathology, Cham, v.88, p.7-37, 2006.

CHANG, S.; PURYEAR, J.; CAIRNEY, J. A simple and efficient method for isolating RNA from pine trees. Plant Molecular Biology Reporter, Charlottesville, v.11, p.113-116, 1993.

DANNENHOFFER, J.M.; SCHULZ, A.; SKAGGS, M.I.; BOSTWICK, D.E.; THOMPSON, G.A. Expression of the phloem lectin is developmentally linked to vascular differentiation in cucurbits. Planta, Berlin, v.201, p.405414, 1997.

DINANT, S.; CLARK, A.M.; ZHU, Y.; VILAINE, F.; PALAUQUI, J.-C.; KUSIAK, C.; THOMPSON, G.A. Diversity of the superfamily of phloem lectins (phloem protein 2) in angiosperms. Plant Physiology, Rockville, v.131, p.114-128, 2003.

DONMEZ, D.; SIMSEK, O.; IZGU, T.; KACAR, Y.A.; MENDI, Y.Y. Genetic transformation in Citrus. The Scientific World Journal, Cairo, v.2013, p.8, 2013.

DOYLE, J.J.; DOYLE, J.L. Isolation of plant DNA from fresh tissue. Focus, Muchen, v.12, p.39-40, 1990.

DUTT, M.; ANANTHAKRISHNAN, G.; JAROMIN, M.K.; BRLANSKY, R.H.; GROSSER, J.W. Evaluation of four phloem-specific promoters in vegetative tissues of transgenic citrus plants. Tree Physiology, Victoria, v.32, p.83-93, 2012.

DUTT, M.; BARTHE, G.; IREY, M.; GROSSER, J. Transgenic citrus expressing an Arabidopsis NPR1 gene exhibit enhanced resistance against huanglongbing (HLB; Citrus Greening). PloS one, San Francisco, n.10, p.e0137134, 2015.

DUTT, M.; DHEKNEY, S.A.; SORIANO, L.; KANDEL, R.; GROSSER, J.W. Temporal and spatial control of gene expression in horticultural crops. Horticulture Research, London, v.1, p.14047, 2014.

ERPEN, L.; TAVANO, E.C.R.; HARAKAVA, R.; DUTT, M.; GROSSER, J.W.; PIEDADE, S.M.S.; MENDES, B.M.J.; MOURÃO FILHO, F.A.A. Isolation, characterization, and evaluation of three Citrus sinensisderived constitutive gene promoters. Plant Cell Reports, Berlin, v.37, p.1113-1125, 2018. 
ETXEBERRIA, E.; NARCISO, C. Phloem Anatomy of Citrus Trees: Healthy vs. Greening-affected. Proceedings of the Florida State Horticultural Society, DeLand, v.125, p.67-70, 2012.

EVERT, R.F. Esau's plant anatomy, meristems, cells, and tissues of the plant body: their structure, function, and development. 3.ed. Hoboken: John Wiley \& Sons, 2006.

FOLIMONOVA, S.Y.; ACHOR, D.S. Early events of citrus greening (Huanglongbing) disease development at the ultrastructural level. Phytopathology, Saint Paul, v.100, p.949-958, 2010.

FOLIMONOVA, S.Y.; ROBERTSON, C.J.; GARNSEY, S.M.; GOWDA, S.; DAWSON, W.O. Examination of the responses of different genotypes of citrus to huanglongbing (Citrus Greening) under different conditions. Phytopathology, Saint Paul, v.99, p.13461354, 2009.

IMLAU, A.; TRUERNIT, E.; SAUER, N. Cell-to-cell and long-distance trafficking of the green fluorescent protein in the phloem and symplastic unloading of the protein into sink tissues. Plant Cell, Rockville, v.11, p.309-322, 1999.

JACOBSEN, E.; SCHOUTEN, H.J. Cisgenesis: an important sub-invention for traditional plant breeding companies. Euphytica, Dordrecht, p.170, p.235, 2009.

JEFFERSON, R.A.; KAVANAGH, T.A.; BEVAN, M.W. GUS fusions: $\beta$-glucuronidase as a sensitive and versatile gene fusion marker in higher plants. The EMBO Journal, Oxford, v.6, p.3901-3907, 1987.

LASSEN, J.; MADSEN, K.; SANDOE, P. Ethics and genetic engineering-lessons to be learned from GM foods. Bioprocess and Biosystems Engineering, Heidelberg, v.24, p.263-271, 2002.

LAY, F.T.; ANDERSON, M.A. Defensins-components of the innate immune system in plants. Current Protein and Peptide Science, Sharjah v.6, p.85-101, 2005.

LOUGH, T.J.; LUCAS, W.J. Integrative plant biology: role of phloem long-distance macromolecular trafficking. Annual Review of Plant Biology, Palo Alto, v.57, p.203232, 2006.

MACHADO, S.R.; CARMELLO-GUERREIRO, S.M. Floema. In: APPEZZATO, B.G.; CARMELLOGUERREIRO, S.M. Anatomia vegetal. 3.ed. Viçosa: UFV Press, 2012.
MAEDA, H.; SONG, W.; SAGE, T.; DELLAPENNA, D. Tocopherols play a crucial role in low-temperature adaptation and phloem loading in Arabidopsis. The Plant Cell, Rockville, v.18, p.2710-2732, 2006.

MAEDA, H.; SONG, W.; SAGE, T.; DELLAPENNA, D. Role of callose synthases in transfer cell wall development in tocopherol deficient Arabidopsis mutants. Frontiers in Plant Science, Lausanne, v.5, p.46, 2014.

MAFRA, V.; MARTINS, P.K.; FRANCISCO, C.S.; RIBEIRO-ALVES, M.; FREITAS-ASTÚA, J.; MACHADO, M.A. Candidatus Liberibacter americanus induces significant reprogramming of the transcriptome of the susceptible citrus genotype. BMC Genomics, Berlin, v.14, p.247, 2013.

MIYATA, L.Y.; HARAKAVA, R.; ATTÍLIO, L.B.; MENDES, B.M.J.; LOPES, J.R.S.; COLETTA-FILHO, H.D.; SOUZA, A.A.; MOURÃO FILHO, F.A.A. Phloem promoters in transgenic sweet orange are differentially triggered by Candidatus Liberibacter asiaticus. Revista Brasileira de Fruticultura, Jaboticabal, v.39, n.3, p.1-9, 2017.

MIYATA, L.Y.; HARAKAVA, R.; STIPP, L.C.L.; MENDES, B.M.J.; APPEZZATO-DA-GLÓRIA, B.; MOURÃO FILHO, F.A.A. GUS expression in sweet oranges (Citrus sinensis L. Osbeck) driven by three different phloem-specific promoters. Plant Cell Reports, Berlin, v.31, p.2005-2013, 2012.

OPARKA, K.J.; TURGEON, R. Sieve elements and companion cells-traffic control centers of the phloem. Plant Cell, Rockville, v.11, p.739-750.1999.

READ, S.M.; NORTHCOTE, D.H. Chemical and immunological similarities between the phloem proteins of three genera of the Cucurbitaceae. Planta, Berlin, v.158, p.119-127, 1983.

RUZIN, S.E. Plant microtechnique and microscopy. New York: Oxford University Press, 1999. 323 p. ]

SCHAART, J.G.; VAN DE WIEL, C.C.M.; LOTZ, L.A.P.; SMULDERS, M.J.M. Opportunities for products of new plant breeding techniques. Trends in Plant Science, Cambridge, v.21, p.438-449, 2016.

SCHNEIDER, H. Anatomy of greening-diseased sweet orange shoots. Phytopathology, Saint Paul, v.58, p.15551160, 1968. 
SILVA, P.A.; FASSINI, C.G.; SAMPAIO, L.S.; DEQUIGIOVANNI, G.; ZUCCHI, M.I.; WULFF, N.A. Genetic Diversity of 'Candidatus Liberibacter asiaticus' Revealed by Short Tandem Repeats and Prophage Typing Indicates Population Homogeneity in Brazil. Phytopathology, Saint Paul, v.109, p.960-971, 2019.

TAVANO, E.C.R.; VIEIRA, M.L.C.; MOURÃO FILHO, F.A.A.; HARAKAVA, R.; MENDES, B.M.J. Genetic transformation of Citrus sinensis "Hamlin" with Attacin a driven by a phloem tissue-specific promoter for resistance to Candidatus Liberibacter spp. Acta Horticulturae, The Hague, v.1065, p.695-702, 2015.

TEIXEIRA, D.C.; DANET, J.L.; EVEILLARD, S.; MARTINS, E.C.; DE JESUS JUNIOR, W.C.; YAMAMOTO, P.T.; LOPES, S.A.; BASSANEZI, R.B.; AYRES, A.J.; SAILlARD, C.; BOVÉ, J.M. Citrus huanglongbing in São Paulo State, Brazil: PCR detection of the 'Candidatus' Liberibacter species associated with the disease. Molecular and Cellular Probes, New York, v.19, p.173-179, 2005.

TRUERNIT, E.; SAUER, N. The promoter of the Arabidopsis thaliana SUC2 sucrose-H+ symporter gene directs expression of $\beta$-glucuronidase to the phloem: evidence for phloem loading and unloading by SUC2. Planta, Berlin, v.196, p.564-570, 1995.

VAN BEL, A.J.E. The phloem, a miracle of ingenuity. Plant, Cell and Environment, Oxford, v.26, p.125-149,
2003.

WANG, M.B.; BOULTER, D.; GATEHOUSE, J.A. A complete sequence of the rice sucrose synthase-1 ( $R S S l)$ gene. Plant Molecular Biology, Dordrecht, v.19, p.881$885,1992$.

YABUTA, Y.; TANAKA, H.; YOSHIMURA, S.; SUZUKI, A.; TAMOI, M.; MARUTA, T.; SHIGEOKA, S. Improvement of vitamin $\mathrm{E}$ quality and quantity in tobacco and lettuce by chloroplast genetic engineering. Transgenic Research, Dordrecht, v.22, p.391-402, 2013.

ZHAO, S.; FERNALD, R.D. Comprehensive algorithm for quantitative real-time polymerase chain reaction. Journal of Computational Biology, Larchmont v.12, p.1047-1064, 2005.

ZHAO, Y.; LIU, Q.Z.; DAVIS, R.E. Transgene expression in strawberries driven by a heterologous phloem-specific promoter. Plant Cell Reports, Berlin, v 23, p.224-230, 2004.

ZOU, X.; SONG, E.; PENG, A.; HE, Y.; XU, L.; LEI, T.; YAO, L.; CHEN, S. Activation of three pathogeninducible promoters in transgenic citrus (Citrus sinensis Osbeck) after Xanthomonas axonopodis pv. citri infection and wounding. Plant Cell, Tissue and Organ Culture, Dordrecht, v.117, p.85-98, 2014. 